\title{
Research Paper: Glycine/NMDA Receptor Pathway Mediates the Rapid-onset Antidepressant Effect of Alkaloids From Trichilia Monadelpha
}

Kennedy Kwami Edem Kukuia ${ }^{*}$ (D), Jeffrey Amoako Mensah ${ }^{2}$ (D), Patrick Amoateng ${ }^{3}$ (D), Dorcas Osei-Safo ${ }^{4}$, Awo Efua Koomson ${ }^{3}$ (D), Joseph Torbi ${ }^{3}$ (D), Donatus Wewura Adongo ${ }^{5}$ (D), Elvis Ofori Ameyaw ${ }^{6}$ (D), Inemesit Okon Ben ${ }^{5}$ (D), Seth Kwabena Amponsah ${ }^{1}$ (D), Kwasi Agyei Bugyei ${ }^{1}$ (D), Isaac Julius Asiedu-Gyekye ${ }^{3}$ (if

1. Department of Medical Pharmacology, University of Ghana Medical School, College of Health Sciences, University of Ghana, Korle Bu-Accra, Ghana. 2. Department of Pharmacology and Toxicology, College of Pharmacy, University of Utah, Salt Lake City, UT, U.S. A.

3. Department of Pharmacology and Toxicology, School of Pharmacy, College of Health Sciences, University of Ghana, Legon-Accra, Ghana.

4. Department of Chemistry, School of Physical and Mathematical Sciences, College of Basic and Applied Sciences, University of Ghana, Legon-Accra, Ghana.

5. Department of Pharmacology and Toxicology, School of Pharmacy, University of Health and Allied Sciences, Ho, Ghana.

6. Department of Pharmacology, School of Pharmacy and Pharmaceutical Sciences, University of Cape Coast, Cape Coast, Ghana.

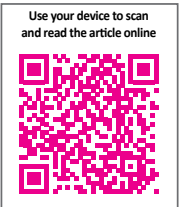

Crtation: Edem Kukuia, K. K., Amoako Mensah, J., Amoateng, P., Osei-Safo, D., Efua Koomson, A., \& Torbi, J., et al. (2021). Glycine/NMDA Receptor Pathway and Mediating the Rapid-onset Antidepressant Effect of Alkaloids Taken From Trichilia Monadelpha. Basic and Clinical Neuroscience, 12(3), 395-408. http://dx.doi.org/10.32598/bcn.12.3.2838.1

http://dx.doi.org/10.32598/bcn.12.3.2838.1

Article info:

Received: 18 Aug 2020

First Revision: 26 Oct 2020

Accepted: 07 Dec 2020

Available Online: 01 May 2021

Keywords:

Glycine/NMDA receptor, Open space swim test, Rapid-acting antidepressant, Trichilia, Alkaloids

\section{ABS T RACT}

Introduction: Major depressive disorder is often associated with suicidal tendencies, and this condition accentuates the need for rapid-acting antidepressants. We previously reported that Alkaloids (ALK) from Trichilia monadelpha possess antidepressant action in acute animal models of depression and that this effect is mediated through the monoamine and L-arginineNO-cGMP pathways. This study investigated the possible rapid-onset antidepressant effect of ALK from T. monadelpha and its connection with the glycine/NMDA receptor pathway.

Methods: The onset of ALK action from T. monadelpha was evaluated using the Open Space Swim Test (OSST), a chronic model of depression. The modified forced swimming and tail suspension tests were used to assess the effect of the ALK on the glycine/NMDA receptor pathway. The Instutute of Cancer Research (ICR) mice were treated with either ALK (30-300 mg/kg, orally [PO]), imipramine (3-30 mg/kg, PO), fluoxetine (3-30 mg/kg, PO), or saline. To identify the role of glycine/NMDA receptor pathway in the effect of ALK, we pretreated mice with a partial agonist of the glycine/NMDA receptor, D-cycloserine $(2.5 \mathrm{mg} /$ $\mathrm{kg}$, intraperitoneally [IP]), and an agonist of glycine/NMDA receptor, D-serine $(600 \mathrm{mg} / \mathrm{kg}$, IP), before ALK administration.

Results: ALK reversed immobility in mice after the second day of drug treatment in the OSST. In contrast, there was a delay in the effects induced by fluoxetine and imipramine. ALK also increased mean swimming and climbing scores in mice. ALK was more efficacious than imipramine and fluoxetine in reducing immobility and increasing distance traveled. It is noteworthy that ALK was less potent than fluoxetine and imipramine. D-cycloserine potentiated mobility observed in the ALK- and fluoxetine-treated mice. In contrast, D-serine decreased mobility in the ALK-treated mice.

Conclusion: The study results suggest that ALK from T. monadelpha exhibits rapid antidepressant action in mice, and the glycine/NMDA receptor pathway possibly mediates the observed effect.

\section{* Corresponding Author:}




\section{Highlights}

- Alkaloids from Trichilia monadelpha are faster in reversing depression-related symptoms in mice when compared to fluoxetine and imipramine.

- Higher doses of Trichilia monadelpha alkaloids are needed to produce the above effect when compared with fluoxetine/ imipramine.

- The glycine/NMDA pathway may be responsible for the rapid-acting antidepressant effect of Trichilia monadelpha.

\section{Plain Language Summary}

When patients are depressed, they normally take medications to get better. These antidepressants normally take a long time before patients to start feeling better. Due to this, scientists have been searching for drugs that will reduce the symptoms of depression faster than the available drugs. This is the purpose of our work. In this work, we tested the effect of some plant constituents called alkaloids from a plant named Trichilia monadelpha. We had previously reported that this plant has antidepressant effect and that the effect was mainly due to its alkaloids. In this present work however, we wanted to find out if the alkaloids in the plant will reverse depressive symptoms faster than fluoxetine and imipramine (two popularly used antidepressants). From our findings, we realized that the alkaloids reversed depressed symptoms many days before the effects of fluoxetine and imipramine were seen. We also wanted to know how the alkaloids were producing this effect. To do this we looked at the effect of the alkaloid on the glycine/NMDA pathway. Our study seem to suggest that the very quick response from the alkaloids may be due to their inhibition of this pathway. Though a drug like ketamine has this effect, its side effect and abuse potential is high and no it is difficult for these drugs to be prescribed on regular basis. Thus, our findings offers the hope that in the near future patients can have a chance of taking antidepressant drugs that can work on the same day without too many serious side effects. It is important to emphasize that further studies are required to better understand what we are seeing.

\section{Introduction}

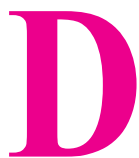

epression is a chronic, recurrent, and debilitating psychiatric disease (Perviz, Khan \& Pervaiz, 2016; Naz et al., 2017; Hashimoto 2019). The neurobiology of depression is associated with monoaminergic dysregulation. Thus, many antidepressants currently used mainly regulate monoamine neurotransmission (Alexander \& Preskorn, 2014; Harmer, Duman \& Cowen, 2017). Although studies show that most antidepressants increase levels of monoamines, this effect does not translate into immediate clinical effects (Trivedi et al., 2006). This issue is presented in a time lag of several weeks before these antidepressants initiate their clinical effect (Skolnick, Popik \& Trullas, 2009). Also, monoamine-modulating antidepressants are effective in about $66.7 \%$ of patients (Wang, Jing, Toledo-Salas \& Xu, 2015). The low response rate and delayed onset of action of current antidepressants are major drawbacks. Furthermore, depression-related suicides have been on the rise in recent years, claiming the lives of about $20 \%$ of depressed patients (Hollon \& Shelton 2001; Centers for Disease Control and Preven- tion, 2020; Curtin, Warner \& Hedegaard, 2016). These challenges accentuate the need for rapid-acting antidepressants (Maeng \& Zarate Jr, 2007; Duman, 2018).

A paradigm shift from focusing on the monoaminergic hypothesis to the N-Methyl-D-Aspartate (NMDA) receptor pathway may represent a considerable advancement in searching for new, effective, and fast-acting antidepressants. NMDA receptor activation requires the presence of two agonists: glutamate and coagonist glycine, at their different binding sites (Cummings \& Popescu, 2015). A wealth of evidence suggests that glutamate alteration or dysregulation in the brain contributes to the pathophysiology of depression (Auer et al., 2000; Küçükibrahimoğlu et al., 2009; Sanacora \& Schatzberg, 2015). Also, preclinical studies in the 1990s suggested that NMDA receptor antagonists had rapid-onset antidepressant effects (Krystal, Sanacora \& Duman, 2013; Serafini, Howland, Rovedi, Girardi \& Amore, 2014; Kraus et al., 2019). D-cycloserine, a partial agonist at the glycine-B coagonist site of NMDA glutamate receptors, could improve mood almost immediately following drug administration (Crane, 1959). Preclinical models have also revealed that other glutamatergic agents such as 
amantadine (NMDA antagonist) and riluzole (glutamate release inhibitors) may have antidepressant properties (Moryl, Danysz \& Quack, 1993; Calabrese et al., 2000; Gourley, Espitia, Sanacora \& Taylor, 2012). Furthermore, some agents that target the glutamatergic signaling pathway improve mood within a short period (Shin et al., 2014). For instance, ketamine, an NMDA receptor antagonist, improves depressive symptoms in patients within few hours (Berman et al., 2000). Thus, the discovery of ketamine and congeners holds tremendous promise to search for rapid and efficacious antidepressants. However, abusive tendency, dissociative and psychotomimetic adverse effects discourage the routine use of ketamine as an antidepressant (Farber, 2003). Therefore, search for other agents with fewer adverse effects is necessary.

Researchers have sought potential sources of practical and rapid-onset antidepressants (Wattanathorn, Pangpookiew, Sripanidkulchai, Muchimapura \& Sripanidkuchai, 2007; Hashimoto, 2019; Kraus et al., 2019). Some of the identified sources of potential antidepressants are plant products (Shi \& Wang, 2006; Freitas et al., 2010; Kwon et al., 2010; Lee et al., 2010; Wang et al., 2010). Trichilia monadelpha is a traditional medicinal plant commonly used to manage various neurological disorders, including depression (No Author, 1927; Shin et al., 2014; Kukuia et al., 2018). The plant has a plethora of bioactive phytochemicals in its stem bark that can be employed to manage treatment-refractory mood-disorders like depression (Lemmens, 2008). Plant secondary metabolites, particularly alkaloids, have emerged as critical pharmacological agents in treating depression (Yao et al., 2009; Martínez-Vázquez et al., 2012; Dhingra \& Valecha, 2014; Perviz et al., 2016). Recently, we reported the antidepressant potential of alkaloids extracted from the stem bark of T. monadelpha (Kukuia et al., 2018) in acute animal models. The present study, thus, sought to evaluate the time of onset of the antidepressant action of total alkaloids taken from $T$. monadelpha in a chronic model of depression and also elucidate the possible involvement of the glycine/NMDA receptor pathway.

\section{Methods}

\subsection{Trichilia monadelpha}

Botanical name: Trichilia monadelpha (Thonn.) J.J. de Wilde; Family: Meliaceae

Indigenous names: Tanduro (Akan), Tenuba (Nzema)

T. monadelpha stem bark was collected from Bomaa, Brong-Ahafo Region, Ghana (7o05 06.60`N,
2010 01.66 'W), and authentication was done at Ghana Herbarium, Department of Botany, the University of Ghana (Voucher No. DPT/JM/001).

\subsection{Geolocation information}

Animal studies were carried out at the Neuropsychopharmacology Laboratory, Department of Medical Pharmacology, University of Ghana, Medical School.

\subsection{Preparation of stem bark extracts}

The stem bark of T. monadelpha was sliced, sun-dried for 14 days, and ground into a fine powder. Using the cold maceration technique, the powdered plant bark was sequentially extracted with petroleum ether $\left(40-60^{\circ} \mathrm{C}\right)$, followed by ethyl acetate, and then $70 \%$ ethanol over 24 hours. Afterward, the ethanolic extract was concentrated under low pressure at $40-60^{\circ} \mathrm{C}$ in a rotary evaporator. The thick mass formed was further dried using a water bath and stored in a desiccator. The percentage yield of the ethanolic extract was $7.3 \% \mathrm{w} / \mathrm{w}$.

\subsection{Preliminary phytochemical screening}

Qualitative screening for alkaloids in the extract was done by following the method of Evans \& Trease (1989).

\subsection{Extraction of alkaloids from the ethanolic fraction}

The extraction method was described by Harborne (1973) and Obadoni \& Ochuko (2002). Briefly, 1 L of $10 \%$ acetic acid in ethanol was added to $50 \mathrm{~g}$ of the ethanolic extract in a beaker. The resulting solution was filtered after being allowed to stand for 4 hours. Drops of $\mathrm{KOH}$ were added to the concentrated obtained from filtration until the formation of a precipitate was complete. The solution was allowed to sediment and the precipitate decanted, washed with diluted $\mathrm{NH}_{4} \mathrm{OH}$, and then filtered. The resulting residue $(14.2 \% \mathrm{w} / \mathrm{w})$ was then collected and dried as total Alkaloids (ALK).

\subsection{Animal husbandry}

Male ICR mice (20-25 g) were purchased from the Noguchi Memorial Institute for Medical Research, University of Ghana, and maintained at the animal facility of the School of Biomedical and Allied Health Science, University of Ghana. The room temperature was kept at 20 $23^{\circ} \mathrm{C}$ with a relative humidity of $60 \%-70 \%$ under $12: 12$ $\mathrm{h}$ light/dark cycle. The animals were housed in cages with wood shavings as bedding and fed with standard commercial feed, and given water freely. The mice were handled according to the Guide for the Care and Use of 
Laboratory Animals (Institute for Laboratory Animal Research, Commission on Life Sciences, Division on Earth and Life Studies, National Research Council, 1996).

\subsection{Drugs and chemicals}

D-cycloserine and D-serine were purchased from Sigma-Aldrich Inc., St. Louis, MO, USA. Imipramine hydrochloride and fluoxetine hydrochloride were obtained from Mallinckrodt Pharmaceuticals, Ireland, and Eli Lilly and Co., Basingstoke, England, respectively.

\subsection{Chronic depression model}

\subsubsection{The open space swim test}

A slight modification to the method described by Stone $\&$ Lin (2011) was done. Swimming was carried out in rat tub cages $(28 \times 26 \times 41 \mathrm{~cm}, \mathrm{w} \times \mathrm{h} \times 1)$ filled with lukewarm water at the height of $13 \mathrm{~cm}\left(32-34^{\circ} \mathrm{C}\right)$. Mice were made to swim individually for $15 \mathrm{~min}$ each day for 4 consecutive days to induce a depressive state characterized by the increase in immobility and diminution of distance traveled by the mice. Drug treatment started from day 5 till day 18. All swim sessions were videotaped from above. No special measures were used to dry or warm the animals as they quickly dried themselves with no visible shivering. The swimming distance was evaluated as the number of quadrants of the tub entered and the duration of immobility from the total time the animal was observed to float.

\subsubsection{Tail Suspension Test (TST)}

The Tail Suspension Test (TST) was carried out as previously described by Steru, Chermat, Thierry \& Simon (1985). Approximately $60 \mathrm{~min}$ after oral administration and $45 \mathrm{~min}$ after intraperitoneal injection of test drugs, the mice were suspended by the tail from a horizontal bar (placed $30 \mathrm{~cm}$ above the floor) using adhesive tape. (distance from the tip of the tail is $1 \mathrm{~cm}$.) The immobility period (defined as the absence of all movements except those required for respiration) was video-recorded for $6 \mathrm{~min}$. Behaviors for the last $4 \mathrm{~min}$ of the 6 minutes were subsequently analyzed. A reduction in the immobility score was the measure for the antidepressant effect.

\subsubsection{Forced Swimming Test (FST)}

The Forced Swimming Test (FST) was implemented as described by Porsolt, Le Pichon \& Jalfre (1977). An hour after oral treatment and $45 \mathrm{~min}$ after intraperitoneal injection of test compounds, the mice were placed separately in polypropylene cylinders (height $25 \mathrm{~cm}$, di- ameter $10 \mathrm{~cm}$ ) containing $10 \mathrm{~cm}$ of water, maintained at $25^{\circ} \mathrm{C}$. The duration of immobility was regarded as the time spent by the mouse floating upright and made only small movements to keep its head above the water. The duration of immobility was scored during the last $4 \mathrm{~min}$ of the 6 min test period. A reduction in immobility score was an indication of the antidepressant effect.

\subsubsection{Design of experiment to indicate the partici- pation of Glycine/NMDA receptor complex}

Mice were initially divided into groups, A and B. Each group was further subdivided into 10 groups each $(n=7)$. Each group of mice from group A was pretreated with D-cycloserine $(2.5 \mathrm{mg} / \mathrm{kg}, \mathrm{IP})$, and $30 \mathrm{~min}$ after, the first three groups received ALK $(30,100$, and $300 \mathrm{mg} / \mathrm{kg}$ ) with the next three groups receiving fluoxetine $(3,10$, and $30 \mathrm{mg} / \mathrm{kg}$ ) and the other three groups receiving imipramine $\left(3,10\right.$ and $30 \mathrm{mg} / \mathrm{kg}$, IP). The $10^{\text {th }}$ group received only D-cycloserine. Ten groups of mice from group B received D-serine $(600 \mathrm{mg} / \mathrm{kg})$ pretreatment, and $30 \mathrm{~min}$ after, the first three groups received an oral dose of the ALK $(30,100$, and $300 \mathrm{mg} / \mathrm{kg}, \mathrm{PO})$ with the following three groups receiving fluoxetine $(3,10$, and $30 \mathrm{mg} / \mathrm{kg}$, $\mathrm{PO})$ and other three groups receiving imipramine $(3,10$, and $30 \mathrm{mg} / \mathrm{kg}$, IP). The $10^{\text {th }}$ group from group B received only D-serine. The FST and TST were used as described above to investigate the antidepressant mechanism.

\subsubsection{Statistical analysis}

For all data and statistical analyses, the GraphPad Prism for windows version 5.03 (GraphPad Software, San Diego, CA, USA) was used. $\mathrm{P}<0.05$ was considered statistically significant. Differences in means were analyzed by 1-way or 2-way ANOVA with either NewmanKeuls or Bonferroni post hoc tests, respectively.

\section{Results}

\subsection{Chronic depression- open space swim test}

From the time-course graph, we observed that mice demonstrated an increase in despair-related behavior by increasing immobility score, decreasing the distance traveled in the first four days before drug treatment (Figures 1,2,3). After drug treatment, however, ALK caused a significant diminution in immobility after day two of treatment (day 6 of the experimental day), and this condition remained until the last day of treatment $\left(\mathrm{F}_{3,68}=21.76\right.$, $\mathrm{P}<0.0001$ ) (Figure 1A). Further, ALK increased the number of quadrants entered (distance travelled) by the mice $\left(\mathrm{F}_{3,68}=14.46, \mathrm{P}<0.0001\right)$ (Figure 1B). Fluoxetine showed 
A

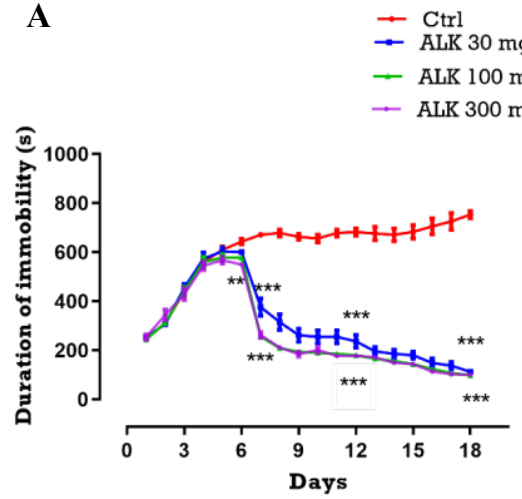

B

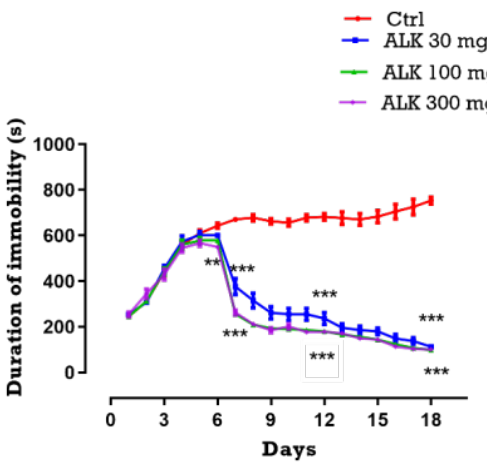

Figure 1. Effects of Alkaloids (ALK) $(30-300 \mathrm{mg} / \mathrm{kg})$ treatment

NEUR SCIENCE

On the A: Period of immobility; and B: the distance travelled in the open space swim test.

Significant differences from the control: ${ }^{*} \mathrm{P}<0.05,{ }^{* *} \mathrm{P}<0.001$, ${ }^{* * *} \mathrm{P}<0.001$ by Newman-Keuls test.

a reduction in immobility time after day 6 of treatment (Figure 2A) but an increased distance traveled on the second day of drug treatment (Figure 2B). Imipramine (IMI) showed a decrease in immobility time after day 6 of treatment (Figure 3A) but a similar effect as ALK with regard to distance traveled (Figure 3B).

\subsection{Dose-response plots}

According to the dose-response curve, higher doses of Alkaloids (ALK), Fluoxetine (FLX), and imipramine (IMI) reduced immobility score while increased distance traveled (Figure 4A \& B). A higher dose of ALK was needed to achieve a $50 \%$ response $\left(\mathrm{ED}_{50}\right)$ as compared to FLX and IMI, suggesting that ALK was less potent than FLX and IMI. ALK was, however, more efficacious than FLX and IMI in reducing immobility time, and increasing distance traveled since it had a higher $\mathrm{E}_{\text {max }}$ (Figure 4 A \& B; Table 1).

\subsection{Involvement of the Glycine/NMDA receptor pathway}

3.3.1. Effect of D-cycloserine pretreatment on immobility behavior

Figure 3 shows the effect of D-cycloserine on ALK, FLX, and IMI treatment in the TST and FST. When administered alone, ALK, FLX, or IMI significantly reduced immobility behavior in mice (Figure 5; untreated). Pretreatment with D-cycloserine $(2.5 \mathrm{mg} / \mathrm{kg}$, IP) caused a further decrease in immobility score in the ALK group (30-300 mg/kg, PO) in both TST $\left(\mathrm{F}_{19,120}=38.86\right.$, $\mathrm{P}<0.0001$; See Figure 5A) and FST $\left(\mathrm{F}_{19,120}=35.46\right.$, $\mathrm{P}<0.0001$; See Figure 5B). In contrast, D-cycloserine pretreatment did not potentiate the effect of FLX (3-30 $\mathrm{mg} / \mathrm{kg}$, PO) or IMI (3-30 mg/kg, PO).
A

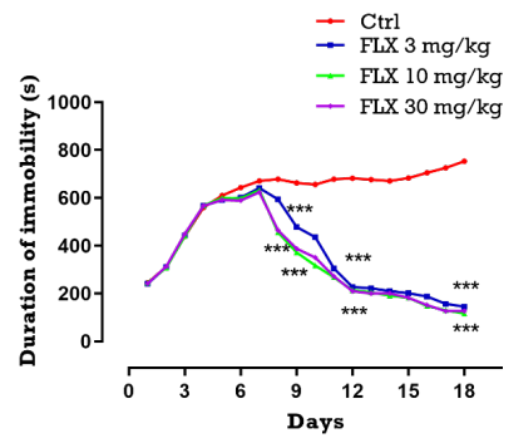

B

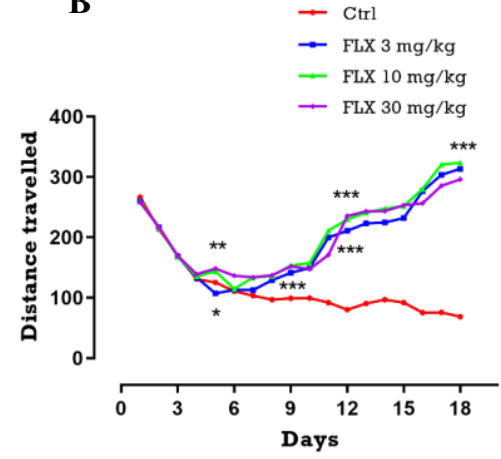

Figure 2. Effects of Fluoxetine (FLX) $(3-30 \mathrm{mg} / \mathrm{kg})$ treatment

On the A: Duration of immobility; and B: The distance travelled in the open space swim test.

Significant differences from the control: ${ }^{*} \mathrm{P}<0.05,{ }^{*} \mathrm{P}<0.001,{ }^{* * *} \mathrm{P}<0.001$ by Newman-Keuls test. 
A

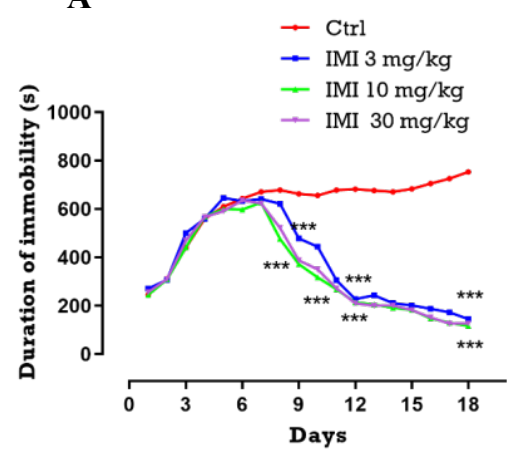

B

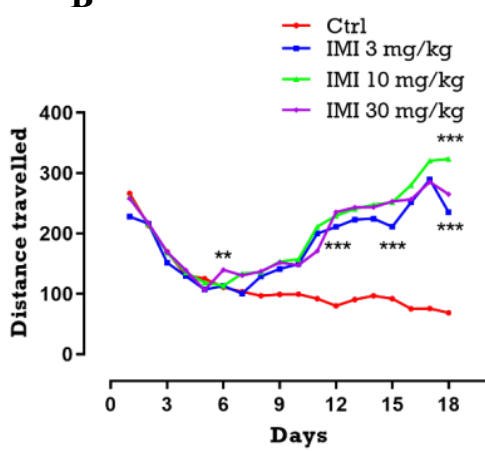

Figure 3. Effects of imipramine (IMI) $(3-30 \mathrm{mg} / \mathrm{kg})$ treatment

NEUR SCIENCE

On the A: Period of immobility; and B: The distance travelled in the open space swim test.

Significant differences from the control: ${ }^{*} \mathrm{P}<0.05,{ }^{*} \mathrm{P}<0.001$, ${ }^{\text {"*w }} \mathrm{P}<0.001$ by Newman-Keuls test.

3.3.2. Effect of D-cycloserine pretreatment on swimming and climbing scores in the FST

Our study showed that ALK (30-300 mg/kg, PO), FLX (3-30 mg/kg, PO), and IMI (3-30 mg/kg, PO) increased swimming behavior in mice (Figure 6). The increase in swimming behavior induced by ALK was further enhanced by D-cycloserine pretreatment (Figure 6A). Mice treated with ALK or FLX did show any significant change in climbing score, unlike the IMI group (Figure 6B).

\subsubsection{D-serine pretreatment}

Figure 7 shows the effect of combined administration of D-serine $(600 \mathrm{mg} / \mathrm{kg}$, IP, a full agonist on glycine/ NMDA receptor) on ALK, FLX, and IMI in TST and FST. The antidepressant effect of ALK $(30,100$, and 300 $\mathrm{mg} / \mathrm{kg}, \mathrm{PO}), \mathrm{FLX}$ (3-30 mg/kg, PO) and IMI (3-30 mg/ $\mathrm{kg}, \mathrm{PO}$ ) was significantly reversed by the pretreatment of D-serine in both (A) TST $\left(\mathrm{F}_{19,120}=67.26, \mathrm{P}<0.0001\right)$ and (B) FST $\left(\mathrm{F}_{19,120}=29.37, \mathrm{P}<0.0001\right)$.
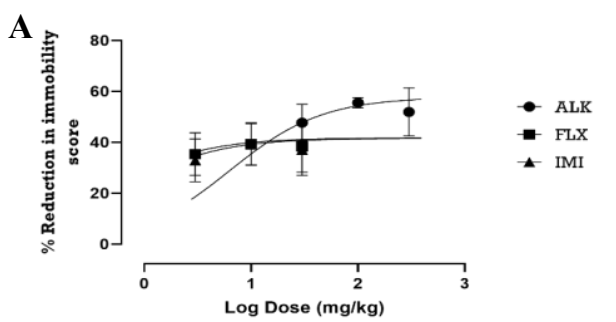

Figure 4. Log dose-response curves
3.3.4. D-serine pretreatment on swimming and climbing scores in FST

ALK, FLX, and IMI increase the swimming score, and this increase was reduced by D-serine in ALK- and FLX-treated mice but unaffected in IMI-treated mice (Figure 8). Climbing scores were increased by ALK (30-300 mg/kg, PO) and IMI (3-30 mg/kg, PO) (Figure $8 \mathrm{~A})$. Pretreatment of D-serine did not affect the climbing score in ALK (300 mg/kg, PO; See Figure 8B).

\section{Discussion}

Several previously studies have reported the role of the glutamatergic and glycine/NMDA receptor complex in the pathophysiology of major depression (Mantovani, Pértile, Calixto, Santos \& Rodrigues, 2003; Matthews, Henter \& Zarate Jr, 2012). Reports also show the efficacy of glutamatergic compounds such as functional glycine/NMDA receptor antagonists as fast-acting antidepressant agents (Zarate et al., 2013). Novel antidepressants with a plant-based origin that possess fast-acting antidepressant effects are required. We investigated the time of onset of the antidepressant action of total alka-

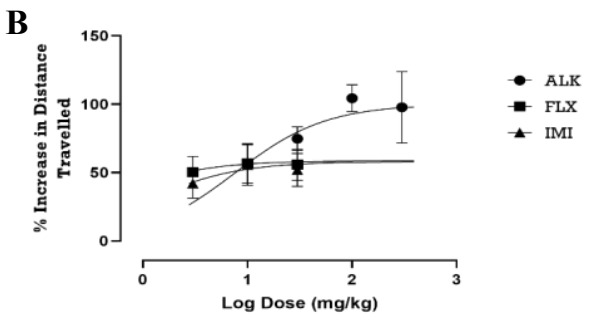

Showing the effect of Alkaloid (ALK) (30-300 mg/kg), Fluoxetine (FLX) (3-30 mg/kg), and Imipramine (IMI) (3-30 mg/kg) on (A) \% decrease in immobility time and (B) \% increase in distance traveled in the open space swim test in mice

Each point represents a percentage decrease of control (Mean $\pm S E M, n=10)$. 
Table 1. $\mathrm{ED}_{50}$ and Emax values of drug treatments in the open space swim test

\begin{tabular}{ccccc}
\hline \multirow{2}{*}{ Treatments } & \multicolumn{2}{c}{ Immobility } & \multicolumn{2}{c}{ Distance Traveled } \\
\cline { 2 - 5 } & $\mathrm{ED}_{50}(\mathrm{mg} / \mathrm{kg})$ & $\mathrm{Emax}$ & $\mathrm{ED}_{50}(\mathrm{mg} / \mathrm{kg})$ & $\mathrm{Emax}$ \\
\hline Alkaloid & 6.307 & 57.80 & 7.656 & 100 \\
Fluoxetine & 0.4582 & 41.75 & 0.4360 & 58.74 \\
Imipramine & 0.6082 & 41.59 & 1.054 & 58.11 \\
\hline
\end{tabular}

NEUR SCIENCE

loids taken from T. monadelpha in a chronic model of depression and also elucidated its possible connection with the glycine/NMDA receptor pathway.

According to our study, stem bark Alkaloids (ALK) taken from $T$. monadelpha exerted rapid antidepressant activity in the open space swim test compared to reference antidepressants like fluoxetine and imipramine. The decrease in immobility time, which is a more reproducible index in determining antidepressant activity in mice using a chronic model (Stone, Lin \& Quartermain, 2008; Stone \& Lin, 2011), began on day 2 of the ALK

A.

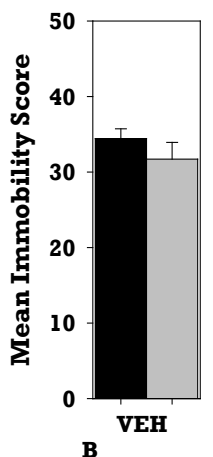

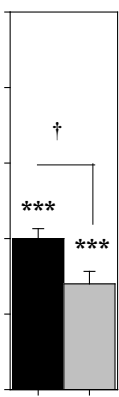

ALK 30
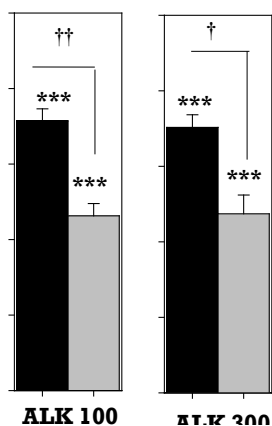

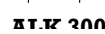

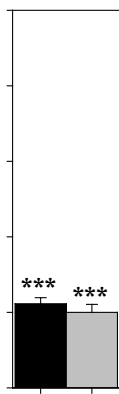

FLX 3

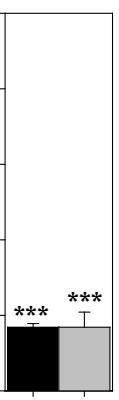

FLXX 10
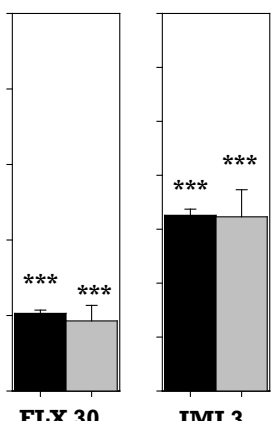

TMT 2

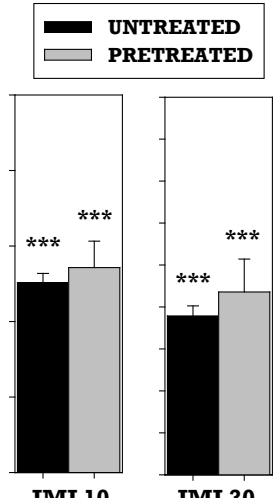

TMrT in

TMrt $2 n$

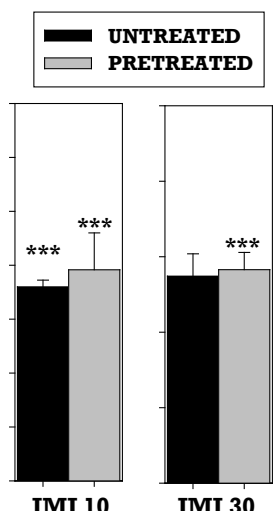

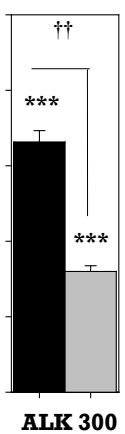
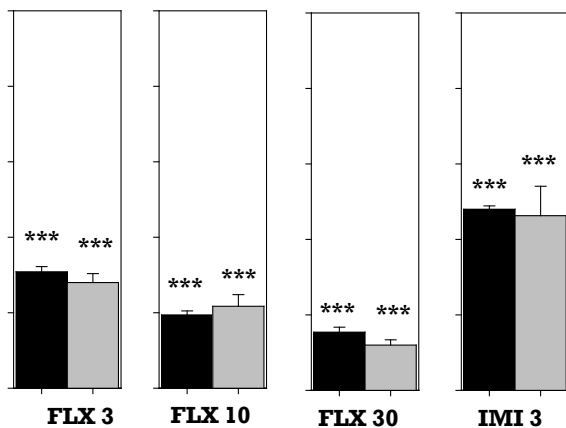

IMI 3
NEUR SCIENCE

IMI 10

Figure 5. Effect of pretreatment of mice

With D-cycloserine $(2.5 \mathrm{mg} / \mathrm{kg}$, IP, a Partial Agonist on Glycine/NMDA receptor on Alkaloid (ALK) (30, 100, and $300 \mathrm{mg} / \mathrm{kg}$, PO) Fluoxetine (FLX) (3, 10, and $30 \mathrm{mg} / \mathrm{kg}$, PO) and Imipramine (IMI) (3,10, and $30 \mathrm{mg} / \mathrm{kg}$, PO) immobility score in the (A) TST and (B) FST.

Each column represents the Mean \pm SEM ( $n=7$ ). Significant differences from vehicle: " $\mathrm{P}<0.0001$; ${ }^{* *} \mathrm{P}<0.001$; ${ }^{*} \mathrm{P}<0.01$ (one-way ANOVA followed by Newman-Keuls test). ${ }^{+t+P}<0.001 ;{ }^{++} \mathrm{P}<0.01$; ${ }^{\mathrm{P}} \mathrm{P}<0.05$. Significant variation between treatment and dose (two-way ANOVA with Bonferroni post hoc test). 

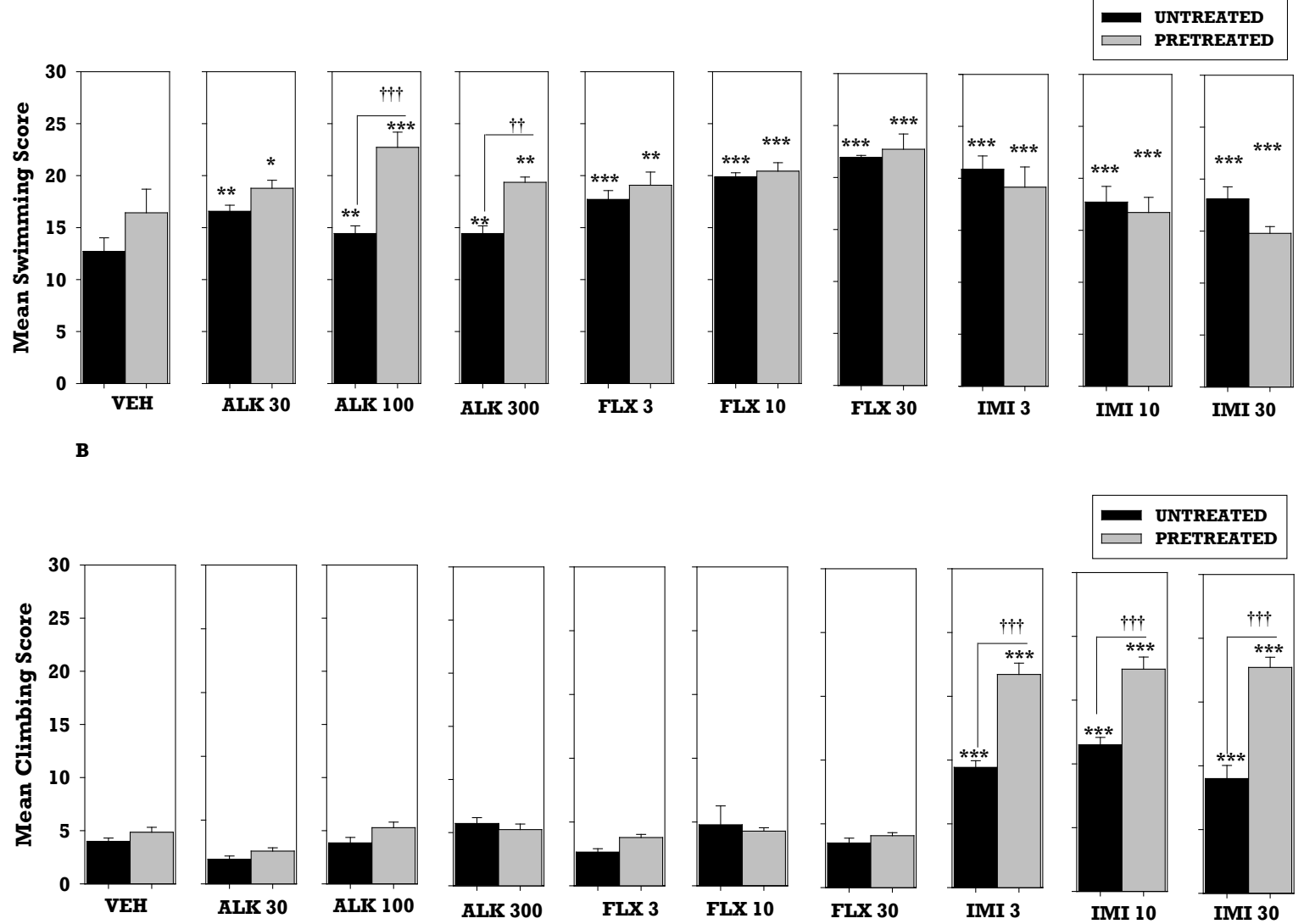

Figure 6. Effect of pretreatment of mice

NEUR SCIENCE

With D-cycloserine on Alkaloid (ALK) (30, 100, and $300 \mathrm{mg} / \mathrm{kg}$, PO), Fluoxetine (FLX) (3, 10, and $30 \mathrm{mg} / \mathrm{kg}$, PO) and Imipramine [IMI] $(3,10$, and $30 \mathrm{mg} / \mathrm{kg}, \mathrm{PO})$ swimming (A) and climbing (B) score in FST

Each column represents the Mean \pm SEM ( $\mathrm{n}=7$ ). Significant differences from vehicle: ${ }^{* * *} \mathrm{P}<0.0001$; " $\mathrm{P}<0.001$; $\mathrm{P}<0.01$ (one-way ANOVA followed by Newman-Keuls test). ${ }^{t t} \mathrm{P}<0.001 ;{ }^{t+\mathrm{P}}<0.01 ; \mathrm{t}<0.05$. Significant difference between treatment and dose (two-way ANOVA with Bonferroni post hoc test).

treatment. ALK increased the number of quadrants visited or distance traveled by mice. A delay in the onset of antidepressant effect was recorded in fluoxetine- and imipramine-treated mice on the sixth and seventh day of treatment, respectively.

Depression is conventionally described as a state of neurotransmitter imbalance, and many antidepressants such as tricyclic antidepressants, selective serotonin reuptake inhibitors, and bupropion have been designed to work via blockade of transporters in the brain (Andrade \& Rao, 2010). The actions mentioned above can be detected immediately after drug administration; however, it takes several weeks to observe the clinically-relevant therapeutic effects of these antidepressants (Frazer \& Benmansour, 2002; Harmer, Goodwin \& Cowen, 2009; Samuels \& Hen, 2011). Reports suggest that depressed patients respond well after chronic treatment with antidepressants (Stone \& Lin, 2011). Studies also indicate a complex sequence of downstream neuropharmacological changes occurring after chronic treatment with antidepressants. It is noteworthy that some of these alterations may contribute to prolonged-time lag in improvement in the depressive symptoms and reduced efficacy (Duman \& Monteggia 2006; Tardito et al., 2006; Harmer et al., 2009; Manji et al., 2003).

Several clinical and preclinical studies have shown the role of functional glycine/NMDA receptor antagonists in managing depression (Dunam \& Li, 2012; Zhu et al., 2013; Gordillo-Salas, Pilar-Cuéllar, Auberson \& Adell, 2018). The current study demonstrated that glycine/NMDA receptor antagonism contributes to the antidepressant-like effect of ALK taken from Trichilia monadelpha in TST and FST. Pretreatment with D-cycloserine further potentiated the mobility effect of ALK in the mice. In contrast, 

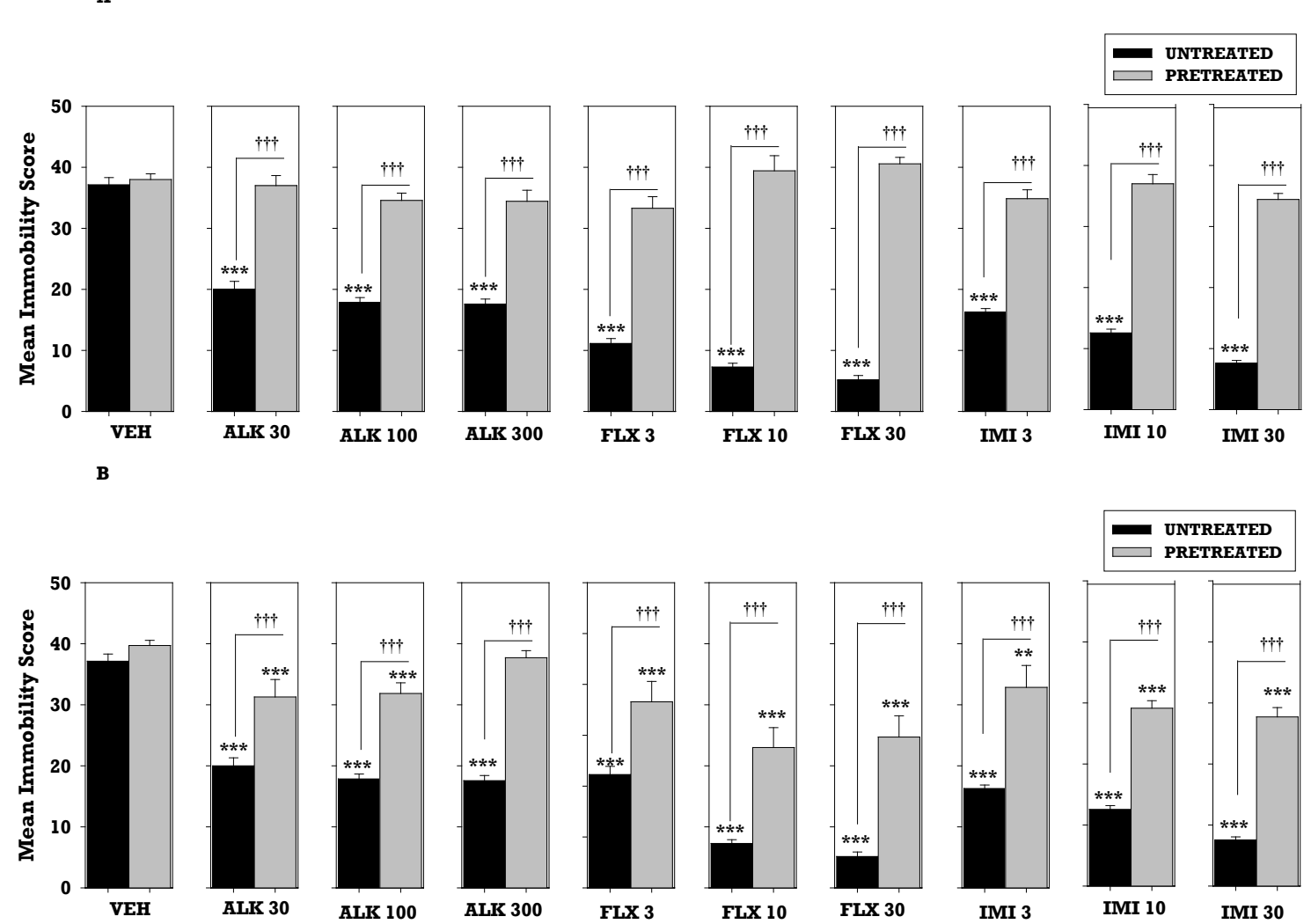

Figure 7. Effect of pretreatment of mice

NEUR SCIENCE

With D-serine (600 mg/kg, IP, a full agonist on Glycine/NMDA receptor) on Alkaloid (ALK) (30, 100, and $300 \mathrm{mg} / \mathrm{kg}$, PO), Fluoxetine (FLX) $(3,10$, and $30 \mathrm{mg} / \mathrm{kg}$, PO) and Imipramine (IMI) $(3,10$, and $30 \mathrm{mg} / \mathrm{kg}$, PO) immobility score in the A: TST; and B: FST.

Each column represents the Mean \pm SEM $(n=7)$. Significant differences from vehicle: " $\mathrm{P}<0.0001$; " $\mathrm{P}<0.001$; " $\mathrm{P}<0.01$ (one-way ANOVA followed by Newman-Keuls test). ${ }^{+1+\mathrm{P}<0.001 ;}+\mathrm{H} \mathrm{P}<0.01 ; \mathrm{T}<0.05$; significant difference between treatment and dose (two-way ANOVA with Bonferroni post hoc test).

pretreatment of D-serine decreased the mobility effect of ALK, FLX, and IMI in the mice. Since D-serine is a full agonist on the glycine/NMDA receptor, the results suggest that activating this receptor complex causes a diminution of antidepressant activity of drugs that work via serotonin and noradrenaline systems (Wlaz' et al., 2011).

The glycine/NMDA receptor antagonistic effect of ALK strongly supports the observed rapid behavioral effect demonstrated in the open space swim test. Recently, it was demonstrated that ketamine (an NMDA receptor antagonist) represents a viable alternative to typical antidepressants with limited efficacy and significant time lag for therapeutic response (Duman \& Li, 2012). However, agents that antagonize at the glycine-B site of NMDA receptors demonstrate relatively few side effects compared to the competitive and non-competitive NMDA antagonists (Poleszak et al., 2011).

In modified FST, drugs that cause an upsurge in swimming scores without significantly changing the climbing score are sensitive to the 5-HTergic pathway. In contrast, drugs with selective effects on catecholamine neurotransmission increase the climbing activity without affecting swimming behavior (Page, Detke, Dalvi, Kirby \& Lucki, 1999; Rénéric, Bouvard \& Stinus, 2001). In this study, mice treated with ALK demonstrated increased swimming behavior which was further potentiated with Dcycloserine pretreatment. There was, however, a reversal of this effect with D-serine pretreatment. Climbing scores of ALK-treated mice were not affected by both D-serine and D-cycloserine pretreatment. This result further supports the theory that interaction between 5-HT receptor and NMDA receptor neurotransmission is more plausible than the noradrenergic and NMDA receptor neurotransmission (Szewczyk et al., 2009; Poleszak et al., 2011).

Our results indicate that stem bark ALK taken from $T$. monadelpha antagonizes glycine/NMDA receptor and probably acts via enhancement of monoaminergic neurotransmission. It is noteworthy that the behavioral effect of ALK remained throughout the experimental period. 

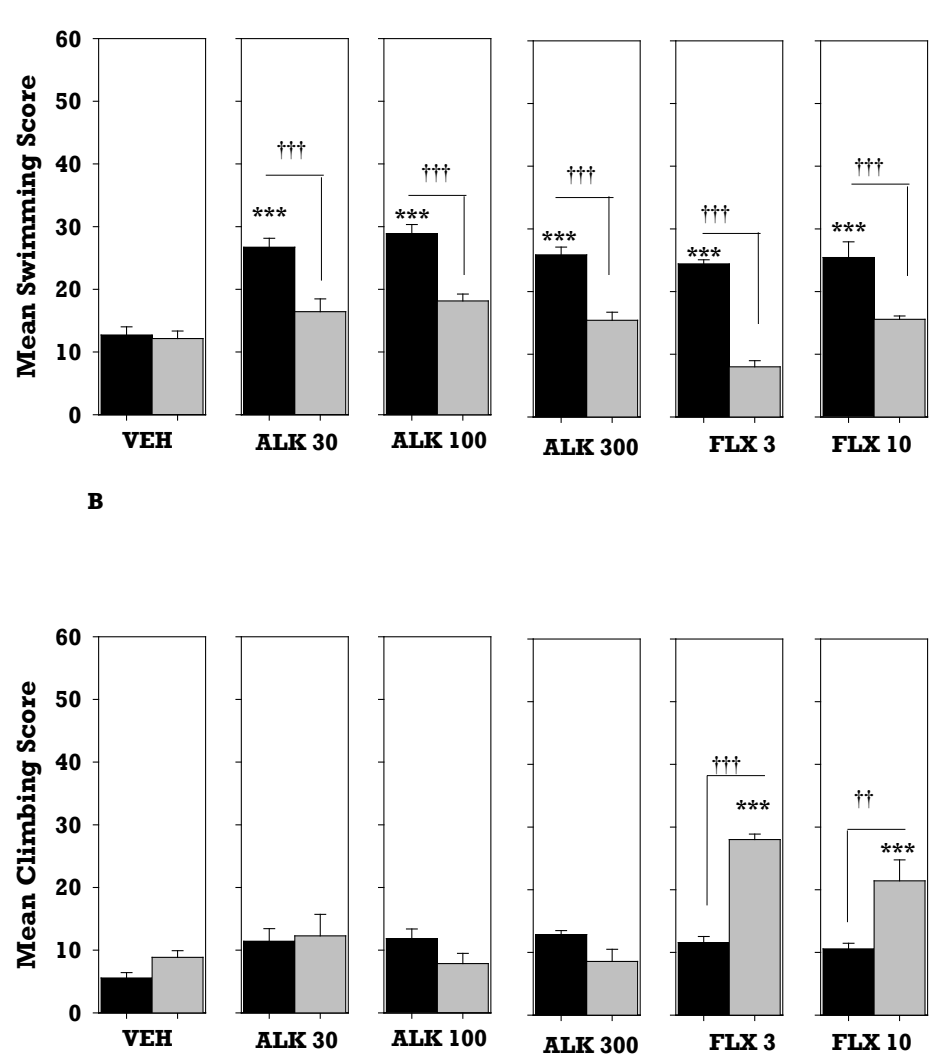

Figure 8. Effect of pretreatment of mice
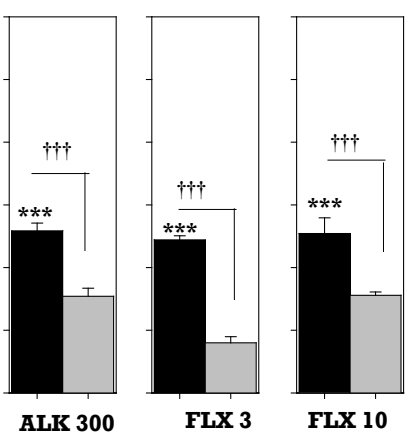
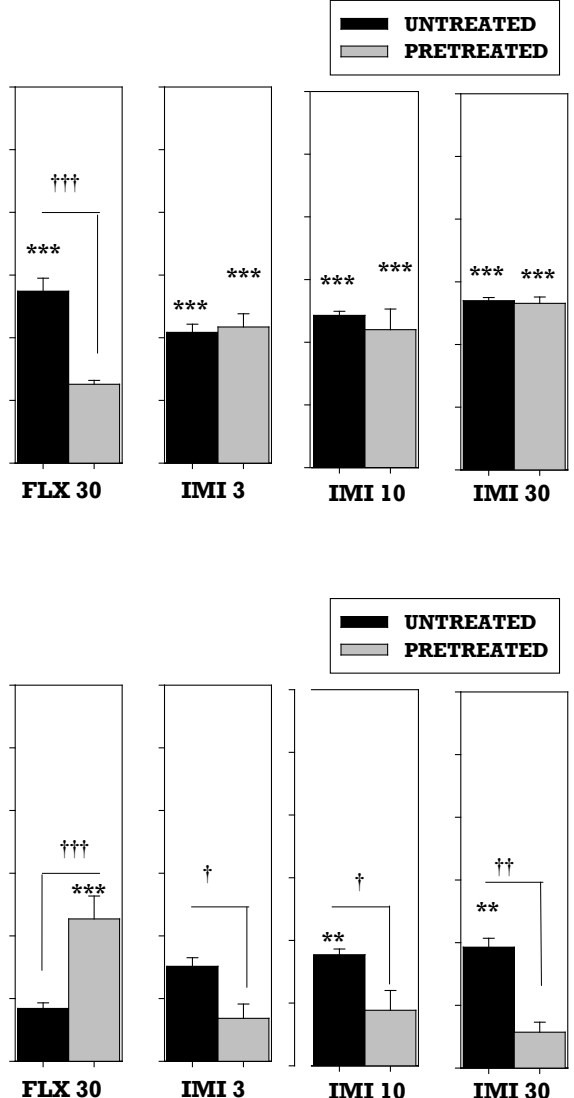

UNTREATED PRETREATED

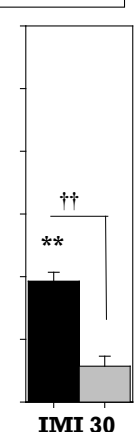

NEUROSCIENCE

With D-serine on Alkaloid (ALK) (30, 100, and $300 \mathrm{mg} / \mathrm{kg}$, PO), Imipramine (IMI) (3, 10, and $30 \mathrm{mg} / \mathrm{kg}$, PO), and Fluoxetine (FLX) (3, 10 , and $30 \mathrm{mg} / \mathrm{kg}$, PO) A: Swimming ;and B: Climbing scores

Each column represents the Mean \pm SEM ( $\mathrm{n}=7$ ). Significantly differences from vehicle: ${ }^{* * *} \mathrm{P}<0.0001$; ${ }^{* *} \mathrm{P}<0.001$; ${ }^{*} \mathrm{P}<0.01$ (one-way ANOVA followed by Newman-Keuls test). ${ }^{+t+P}<0.001 ;+\mathrm{H} P<0.01 ;+\mathrm{P}<0.05$; Significant variance between treatment and dose (two-way ANOVA with Bonferroni post hoc test).

\section{Conclusion}

Total alkaloids taken from Trichilia monadelpha exhibited a rapid-onset antidepressant effect when given to mice, and glycine/NMDA antagonism may mediate this observed effect.

\section{Ethical Considerations}

\section{Compliance with ethical guidelines}

This study was ethically approved by the National Institutional Animal Care and Use Committee, Noguchi Memorial Institute for Medical Research, University of Ghana (Protocol no.: 2014-02-4N).
Funding

This research was supported by a seed grant from the University of Ghana Research Fund (Grant No. URF.7.SF-011.2013-2).

\section{Authors' contributions}

Conceptualization: Kennedy Kwami Edem Kukuia, Jeffrey Amoako Mensah; Methodology \& investigation: Kennedy Kwami Edem Kukuia, Jeffrey Amoako Mensah; Data collection and data analysis: Kennedy Kwami Edem Kukuia, Jeffrey Amoako Mensah, Patrick Amoateng, Isaac Julius Asiedu-Gyekye; Writing - review \& editing, writing - Original draft preparation: All authors. 


\section{Conflict of interest}

The authors declared no conflict of interest.

\section{Acknowledgments}

We wish to thank all technical staff in the Department of Pharmacology and Toxicology, School of Pharmacy, University of Ghana.

\section{References}

Alexander, R. C., \& Preskorn, Sh. (2014). Clinical pharmacology in the development of new antidepressants: The challenges. Current Opinion in Pharmacology, 14, 6-10. [DOI:10.1016/j. coph.2013.09.016] [PMID]

Andrade, Ch., \& Rao, N. S. K. (2010). How antidepressant drugs act: A primer on neuroplasticity as the eventual mediator of antidepressant efficacy. Indian Journal of Psychiatry, 52(4), 37886. [DOI:10.4103/0019-5545.74318] [PMID] [PMCID]

Auer, D. P., Pütz, B., Kraft, E., Lipinski, B., Schill, J., \& Holsboer F. (2000). Reduced glutamate in the anterior cingulate cortex in depression: An in vivo proton magnetic resonance spectroscopy study. Biological Psychiatry, 47(4), 305-13. [DOI:10.1016/ S0006-3223(99)00159-6]

Berman, R. M., Cappiello, A., Anand, A., Oren, D. A., Heninger, G. R., \& Charney, D. S., et al. (2000). Antidepressant effects of ketamine in depressed patients. Biological Psychiatry, 47(4), 351-4. [DOI:10.1016/S0006-3223(99)00230-9]

Calabrese, J. R., Suppes, T., Bowden, C. L., Sachs, G. S., Swann A. C., \& McElroy, S. L., et al. (2000). A double-blind, placebocontrolled, prophylaxis study of lamotrigine in rapid-cycling bipolar disorder. The Journal of Clinical Psychiatry, 61(11), 84150. [DOI:10.4088/JCP.v61n1106] [PMID]

Centers for Disease Control and Prevention (CDC). (2020). National Violent Death Reporting System (NVDRS). Retrieved from https://www.cdc.gov/violenceprevention/datasources/nvdrs/index.html

Crane, G. E. (1959). Cycloserine as an antidepressant agent. The American Journal of Psychiatry, 115(11), 1025-6. [DOI:10.1176/ ajp.115.11.1025] [PMID]

Cummings, K. A., \& Popescu, G. K. (2015). Glycine-dependent activation of NMDA receptors. Journal of General Physiology, 145(6), 513-27. [DOI:10.1085/jgp.201411302] [PMID] [PMCID]

Curtin, S. C., Warner, M., \& Hedegaard, H. (2016). Increase in suicide in the United States, 1999-2014. NCHS Data Brief, (241), 1-8. [PMID]

Dhingra, D., \& Valecha, R. (2014). Punarnavine, an alkaloid isolated from ethanolic extract of Boerhaavia diffusa Linn. reverses depression-like behaviour in mice subjected to chronic unpredictable mild stress. Indian Journal of Experimental Biology, 52(8), 799-807. [PMID]
Duman, R. S. (2018). Ketamine and rapid-acting antidepressants: A new era in the battle against depression and suicide [version 1; peer review: 3 approved]. F1000Research, 7: F1000 Faculty Rev-659. [DOI:10.12688/f1000research.14344.1] [PMID] [PMCID]

Duman, R. S., \& Monteggia, L. M. (2006). A neurotrophic model for stress-related mood disorders. Biological Psychiatry, 59(12), 1116-27. [DOI:10.1016/j.biopsych.2006.02.013] [PMID]

Duman, R. S., \& Li, N. (2012). A neurotrophic hypothesis of depression: Role of synaptogenesis in the actions of NMDA receptor antagonists. Philosophical Transactions of the Royal Society B Biological Sciences, 367(1601), 2475-84. [DOI:10.1098/ rstb.2011.0357] [PMID] [PMCID]

Evans, W. Ch., \& Trease, G. E. (1989). Trease and Evans' pharmacognosy. London: Baillière Tindall. https://www.worldcat. org/title/trease-and-evans-pharmacognosy/oclc/21198097

Farber, N. B. (2003). The NMDA receptor hypofunction model of psychosis. Annals of the New York Academy of Sciences, 1003(1), 119-30. [DOI:10.1196/annals.1300.008] [PMID]

Frazer, A., \& Benmansour, S. (2002). Delayed pharmacological effects of antidepressants. Molecular Psychiatry, 7 Suppl 1, S238. [DOI:10.1038/sj.mp.4001015] [PMID]

Freitas, A. E., Budni, J., Lobato, K. R., Binfaré, R. W., Machado, D. G., \& Jacinto, J., et al. (2010). Antidepressant-like action of the ethanolic extract from Tabebuia avellanedae in mice: Evidence for the involvement of the monoaminergic system. Progress in Neuro-Psychopharmacology and Biological Psychiatry 34(2), 335-43. [DOI:10.1016/j.pnpbp.2009.12.010] [PMID]

Gordillo-Salas, M., Pilar-Cuéllar, F., Auberson, Y. P., \& Adell A. (2018). Signaling pathways responsible for the rapid antidepressant-like effects of a GluN2A-preferring NMDA receptor antagonist. Translational Psychiatry, 8, 84. [DOI:10.1038/ s41398-018-0131-9]

Gourley, Sh. L., Espitia, J. W., Sanacora, G., \& Taylor, J. R. (2012) Antidepressant-like properties of oral riluzole and utility of incentive disengagement models of depression in mice. Psychopharmacology, 219(3), 805-14. [DOI:10.1007/s00213-0112403-4] [PMID] [PMCID]

Harborne, J. B. (1973). Methods of plant analysis. In J. B. Harborne. Phytochemical methods: A guide to modern techniques of plant analysis (pp. 1-32). London: Chapman and Hall [DOI:10.1007/978-94-009-5921-7_1]

Harmer, C. J., Duman, R. S., \& Cowen, P. J. (2017). How do antidepressants work? New perspectives for refining future treatment approaches. The Lancet Psychiatry, 4(5), 409-18. [DOI:10.1016/S2215-0366(17)30015-9]

Harmer, C. J., Goodwin, G. M., \& Cowen, P. J. (2009). Why do antidepressants take so long to work? A cognitive neuropsychological model of antidepressant drug action. The British Journal of Psychiatry, 195(2), 102-8. [DOI:10.1192/bjp. bp.108.051193] [PMID]

Hashimoto, K. (2019). Rapid-acting antidepressant ketamine, its metabolites and other candidates: A historical overview and future perspective. Psychiatry and Clinical Neurosciences, 73(10), 613-27. [DOI:10.1111/pcn.12902] [PMID] [PMCID]

Hollon, S. D., \& Shelton, R. C. (2001). Treatment guidelines for major depressive disorder. Behavior Therapy, 32(2), 235-58. [DOI:10.1016/S0005-7894(01)80004-6] 
Institute for Laboratory Animal Research, Commission on Life Sciences, Division on Earth and Life Studies, National Research Council. (1996). Guide for the care and use of laboratory animals. Washington, D.C.: National Academies Pressy. https:/ / books.google.com/books?id=o7qjhbBESMEC\&dq

Kraus, Ch., Wasserman, D., Henter, I. D., Acevedo-Diaz, E., Kadriu, B., \& Zarate Jr, C. A. (2019). The influence of ketamine on drug discovery in depression. Drug Discovery Today, 24(10), 2033-43. [DOI:10.1016/j.drudis.2019.07.007] [PMID] [PMCID]

Krystal, J. H., Sanacora, G., \& Duman, R. S. (2013). Rapid-acting glutamatergic antidepressants: The path to ketamine and beyond. Biological Psychiatry, 73(12), 1133-41. [DOI:10.1016/j. biopsych.2013.03.026] [PMID] [PMCID]

Küçükibrahimoğlu, E., Saygin, M. Z., Calişkan, M., Kaplan, O. K., Ünsal, C., \& Zafer Gören, M. (2009). The change in plasma GABA, glutamine and glutamate levels in fluoxetine- or S-citalopram-treated female patients with major depression. European Journal of Clinical Pharmacology, 65(6), 571-7. [DOI:10.1007/s00228-009-0650-7] [PMID]

Kukuia, K. K. E., Mensah, J. A., Amoateng, P., Amponsah, S. K., N'Guessan, B. B., \& Asiedu-Gyekye, I. J. (2018). Antidepressant potentials of components from Trichilia monadelpha (Thonn.) J.J. de Wilde in murine models. Evidence-Based Complementary and Alternative Medicine, 2018, 6863973. [DOI:10.1155/2018/6863973] [PMID] [PMCID]

Kwon, S., Lee, B., Kim, M., Lee, H., Park, H. J., \& Hahm, D. H. (2010). Antidepressant-like effect of the methanolic extract from Bupleurum falcatum in the tail suspension test. Progress in Neuro-Psychopharmacology and Biological Psychiatry, 34(2) 265-70. [DOI:10.1016/j.pnpbp.2009.11.015] [PMID]

Lee, S., Kim, D. H., Lee, Ch. H., Jung, J. W., Seo, Y. T., \& Jang, Y. P., et al. (2010). Antidepressant-like activity of the aqueous extract of Allium macrostemon in mice. Journal of Ethnopharmacology, 131(2), 386-95. [DOI:10.1016/j.jep.2010.07.015] [PMID]

Lemmens, R. H. M. J. (2008). Trichilia monadelpha (Thonn.) J.J. de Wilde. In D. Louppe, A. A. Oteng-Amoako, \& M. Brink, (Eds.), Plant Resources of Tropical Africa 7(1). Timbers 1 (pp. 561-563). Wageningen, Netherlands: PROTA Foundation/ Backhuys Publishers/CTA. https://books.google.com/ books?id=-nw-mZQ0kcEC\&dq

Maeng, S., \& Zarate Jr, C. A. (2007). The role of glutamate in mood disorders: Results from the ketamine in major depression study and the presumed cellular mechanism underlying its antidepressant effects. Current Psychiatry Reports, 9(6), 46774. [DOI:10.1007/s11920-007-0063-1] [PMID]

Manji, H. K., Quiroz, J. A., Sporn, J., Payne, J. L., Denicoff, K., \& Gray, N. A., et al. (2003). Enhancing neuronal plasticity and cellular resilience to develop novel, improved therapeutics for difficult-to-treat depression. Biological Psychiatry, 53(8), 707-42. [DOI:10.1016/S0006-3223(03)00117-3]

Mantovani, M., Pértile, R., Calixto, J. B., Santos, A. R. S., \& Rodrigues, A. L. S. (2003). Melatonin exerts an antidepressantlike effect in the tail suspension test in mice: Evidence for involvement of the N-methyl-D-aspartate receptors and the L-arginine-nitric oxide pathway. Neuroscience Letters, 343(1), 1-4. [DOI:10.1016/S0304-3940(03)00306-9]

Mathews, D. C., Henter, I. D., \& Zarate Jr, C. A. (2012). Targeting the glutamatergic system to treat major depressive disorder: Rationale and progress to date. Drugs, 72(10), 1313-33. [DOI:10.2165/11633130-000000000-00000] [PMID] [PMCID]
Martínez-Vázquez, M., Estrada-Reyes, R., Araujo Escalona, A G., Ledesma Velázquez, I., Martínez-Mota, L., \& Moreno, J., et al. (2012). Antidepressant-like effects of an alkaloid extract of the aerial parts of Annona cherimolia in mice. Journal of Ethnopharmacology, 139(1), 164-70. [DOI:10.1016/j. jep.2011.10.033] [PMID]

Moryl, E., Danysz, W., \& Quack, G. (1993). Potential antidepressive properties of amantadine, memantine and bifemelane. Pharmacology \& Toxicology, 72(6), 394-7. [DOI:10.1111/j.1600-0773.1993.tb01351.x] [PMID]

Naz, S., Farooq, U., Khan, A., Khan, H., Karim, N., \& Sarwar, R. et al. (2017). Antidepressent effect of two new benzyl derivatives from wild strawberry Fragaria vesca var. nubicola Lindl. ex Hook.f. Frontiers in Pharmacology, 8, 469. [DOI:10.3389/ fphar.2017.00469] [PMID] [PMCID]

No Author. (1927). The Flora of West Tropical Africa. Bulletin of Miscellaneous Information (Royal Botanic Gardens, Kew), 1927(4), 145-50. [DOI:10.2307/4107588]

Obadoni, B. O., \& Ochuko, P. O. (2002). Phytochemical studies and comparative efficacy of the crude extracts of some haemostatic plants in Edo and Delta States of Nigeria. Global Journal of Pure and Applied Sciences, 8(2), 203-8. [DOI:10.4314/ gjpas.v8i2.16033]

Page, M. E., Detke, M. J., Dalvi, A., Kirby, L. G., \& Lucki, I (1999). Serotonergic mediation of the effects of fluoxetine, but not desipramine, in the rat forced swimming test. Psychopharmacology, 147(2), 162-7. [DOI:10.1007/s002130051156] [PMID]

Perviz, S., Khan, H., \& Pervaiz, A. (2016). Plant alkaloids as an emerging therapeutic alternative for the treatment of depression. Frontiers in Pharmacology, 7, 28. [DOI:10.3389/ fphar.2016.00028] [PMID] [PMCID]

Poleszak, E., Wlaź, P., Szewczyk, B., Wlaź, A., Kasperek, R., \& Wróbel, A., et al. (2011). A complex interaction between glycine/NMDA receptors and serotonergic/noradrenergic antidepressants in the forced swim test in mice. Journal of Neural Transmission, 118(11), 1535-46. [DOI:10.1007/s00702011-0630-9] [PMID] [PMCID]

Porsolt, R. D., Le Pichon, M., \& Jalfre, M. (1977). Depression: A new animal model sensitive to antidepressant treatments. $\mathrm{Na}$ ture, 266(5604), 730-2. [DOI:10.1038/266730a0] [PMID]

Rénéric, J. Ph., Bouvard, M., \& Stinus, L. (2001). Idazoxan and 8-OHDPAT modify the behavioral effects induced by either NA, or 5-HT, or dual NA/5-HT reuptake inhibition in the rat forced swimming test. Neuropsychopharmacology, 24, 379-90. [DOI:10.1016/S0893-133X(00)00214-1]

Sanacora, G., \& Schatzberg, A. F. (2015). Ketamine: Promising path or false prophecy in the development of novel therapeutics for mood disorders? Neuropsychopharmacology, 40(2), 25967. [DOI:10.1038/npp.2014.261] [PMID] [PMCID]

Samuels, B. A., \& Hen, R. (2011). Neurogenesis and affective disorders. European Journal of Neuroscience, 33(6), 1152-9. [DOI:10.1111/j.1460-9568.2011.07614.x] [PMID]

Serafini, G., Howland, R. H., Rovedi, F., Girardi, P., \& Amore, M. (2014). The role of ketamine in treatment-resistant depression: A systematic review. Current Neuropharmacology, 12(5), 444-61. [DOI:10.2174/1570159X12666140619204251] [PMID] [PMCID] 
Shin, I. J., Son, S. U., Park, H., Kim, Y., Park, S. H., \& Swanberg K., et al. (2014). Preclinical evidence of rapid-onset antidepressant-like effect in radix polygalae extract. PLoS One, 9(2), e88617. [DOI:10.1371/journal.pone.0088617] [PMID] [PMCID]

Shi, Y., \& Wang, H. (2006). [Antidepressant activity of extract of hypericum perforatum with enriched flavonoids (Chinese)] Traditional Chinese Drug Research \& Clinical Pharmacology, (1): 4-7. https://caod.oriprobe.com/articles/10050389/Antidepressant_Activity_of_Extract_of_Hypericum_perforatum_ with Enrich.htm

Skolnick, Ph., Popik, P., \& Trullas, R. (2009). Glutamate-based antidepressants: 20 years on. Trends in Pharmacological Sciences, 30(11), 563-9. [DOI:10.1016/j.tips.2009.09.002] [PMID]

Steru, L., Chermat, R., Thierry, B., \& Simon, P. (1985). The tail suspension test: A new model for screening antidepressants in mice. Psychopharmacology, 85(3), 367-70. [DOI:10.1007/ BF00428203] [PMID]

Stone, E. A., \& Lin, Y. (2011). Open-space forced swim model of depression for mice. Current Protocols in Neuroscience, Chapter 9, Unit 9.36. [DOI:10.1002/0471142301.ns0936s54] [PMID] [PMCID]

Stone, E. A., Lin, Y., \& Quartermain, D. (2008). Evaluation of the repeated open-space swim model of depression in the mouse. Pharmacology Biochemistry and Behavior, 91(1), 190-5. [DOI:10.1016/j.pbb.2008.07.006] [PMID] [PMCID]

Szewczyk, B., Poleszak, E., Wlaź, P., Wróbel, A., Blicharska, E. \& Cichy, A., et al. (2009). The involvement of serotonergic system in the antidepressant effect of zinc in the forced swim test. Progress in Neuro- Psychopharmacology and Biological Psychiatry, 33(2), 323-9. [DOI:10.1016/j.pnpbp.2008.12.011] [PMID]

Tardito, D., Perez, J., Tiraboschi, E., Musazzi, L., Racagni, G., \& Popoli, M. (2006). Signaling pathways regulating gene expression, neuroplascticity and neurotrophic mechanisms in the action of antidepressant: A critical overview. Pharmacological Reviews, 58(1), 115-34. [DOI:10.1124/pr.58.1.7] [PMID]

Trivedi, M. H., John Rush, A., Wisniewski, S. R., Nierenberg, A. A., Warden, D., \& Ritz, L., et al. (2006). Evaluation of outcomes with citalopram for depression using measurementbased care in STAR*D: Implications for clinical practice. The American Journal of Psychiatry, 163(1), 28-40. [DOI:10.1176/ appi.ajp.163.1.28

Wang, J., Jing, L., Toledo-Salas, J. C., \& Xu, L. (2015). Rapid-onset antidepressant efficacy of glutamatergic system modulators: The neural plasticity hypothesis of depression. Neuroscience Bulletin, 31(1), 75-86. [DOI:10.1007/s12264-014-1484-6] [PMID] [PMCID]

Wang, Y.,Han, T., Zhu, Y., Zheng, Ch. J., Ming, Q. L., \& Rahman, Kh., et al. (2010). Antidepressant properties of bioactive fractions from the extract of Crocus sativus L. Journal of Natural Medicines, 64(1), 24. [DOI:10.1007/s11418-009-0360-6] [PMID]

Wattanathorn, J., Pangpookiew, P., Sripanidkulchai, K., Muchimapura, S., \& Sripanidkuchai, B. (2007). Evaluation of the anxiolytic and antidepressant effects of alcoholic extract of Kaempferia parviflora in aged rats. American Journal of Agricultural and Biological Sciences, 2(2), 94-8. https://thescipub. com/abstract/10.3844/ajabssp.2007.94.98

Wlaz', P., Kasperek, R., Wlaz', A., Szumiło, M., Wróbel, A., \& Nowak, G., et al. (2011). NMDA and AMPA receptors are involved in the antidepressant-like activity of tianeptine in the forced swim test in mice. Pharmacological Reports, 63(6), 152632. [DOI:10.1016/S1734-1140(11)70716-2]
Yao, C. Y., Wang, J., Dong, D., Oian, F. G., Xie, J., \& Pan, S. L. (2009). Laetispicine, an amide alkaloid from Piper laetispicum, presents antidepressant and antinociceptive effects in mice. Phytomedicine, 16(9), 823-9. [DOI:10.1016/j. phymed.2009.02.008] [PMID]

Zarate, C., Duman, R. S., Liu, G., Sartori, S., Quiroz, J., \& Murck, H. (2013). New paradigms for treatment-resistant depression. Annals of the New York Academy of Sciences, 1292(1), 21-31. [DOI:10.1111/nyas.12223] [PMID] [PMCID]

Zhu, W. L., Wang, Sh. J., Liu, M. M., Shi, H. Sh., Zhang, R. X., \& Liu, J. F., et al. (2013). Glycine site N-methyl-D-aspartate receptor antagonist 7-CTKA produces rapid antidepressantlike effects in male rats. Journal of Psychiatry $\mathcal{E}$ Neuroscience, 38(5), 306-16. [DOI:10.1503/jpn.120228] [PMID] [PMCID] 
This Page Intentionally Left Blank 